\title{
Overwintering mortality of the oak lace bug (Corythucha arcuata) in Hungary - a field survey
}

\author{
Márton Paulin ${ }^{1}$, Anikó Hirka ${ }^{1}$, Mariann Csepelényi ${ }^{2}$, Ágnes Fürjes-Mikó ${ }^{1}$, Imola \\ Tenorio-Baigorria ${ }^{1}$, Csaba Eötvös ${ }^{1}$, Csaba Gáspár ${ }^{1}$ and György Csóka ${ }^{1 *}$ \\ ${ }^{1}$ Forest Research Institute, Department of Forest Protection, 18 Hegyalja str., H - 3232 Mátrafüred, Hungary \\ ${ }^{2}$ Szent István University, Institute of Plant Protection, 1 Páter Károly str., H - 2100 Gödöllö, Hungary
}

\begin{abstract}
The North American oak lace bug (Corythucha arcuata) was first discovered in Europe (Norhern Italy) in 2000. It started a rapid area expansion in the last decade and has been reported in 20 countries so far. Almost all European oaks are suitable hosts. On top of the host availability, abiotic factors like weather/climate may also have a decisive impact on its further spread and future outbreaks. We conducted a simple field survey within three years, at five locations to estimate the overwintering mortality of the species. Our results suggest that not even a relatively harsh winter (as 2016/2017) caused severe mortality in the overwintering populations. The average mortality of the nine year/location combinations was $30.6 \%$ (range 9.1-58.5\%). Based on this, the low winter temperature is unlikely to restrict its further spread, therefore continuing area expansion can be predicted.
\end{abstract}

Key words: invasive insects; area expansion; climate change; abiotic limitation; overwintering success

Editor: Juraj Galko

\section{Introduction}

Alien species are appearing at an accelerated rate worldwide, including European countries (Roques 2010; Csóka et al. 2010; 2012; Tuba et al. 2012; Smith et al. 2018). While some of them do not have any evident impact in the newly colonized areas, others may become invasive, rapidly expanding their area and imposing severe pressure on the invaded area's ecosystems both from an economic and an ecological point of view. The chance of a non-native species becoming invasive strongly depends on the suitability of the environmental conditions including availability of host plants (Csóka et al. 2019; Paulin et al. 2020), effects of native natural enemies (Csóka et al. 2009; Panzavolta et al. 2018; Kos et al. 2020). The weather and climate may also be decisive factors from the point of the establishment and the future of the established populations. Different weather parameters may have different impacts on the different life stages of insects (Neuvonen \& Virtanen 2015). Among many others, overwintering success is an extremely important issue (Leather et al. 1993; Marshall et al. 2020; Vétek et al. 2020). Cold winter temperatures have both lethal and sub-lethal impacts on overwintering insects (Turnock \& Fields 2005; Scaccini et al.2020). Any information on the overwintering success of a new non-native insect is vital to make predictions on its further spread and expected importance.

Insects can be classified as either freeze-tolerant or freeze-intolerant (or freeze-avoidant). The extracellular freezing is not lethal for the freeze-tolerant, they regularly freeze between -5 to $-10^{\circ} \mathrm{C}$, or at even lower temperature. After this they can be cooled to far lower temperatures (some species even as low as $-50^{\circ} \mathrm{C}$ ). With temperature increase they thaw and recover showing normal functions and development (Bale 1993). The freeze intolerant (freeze-avoidant) insect may avoid freezing by lowering their super cooling point (SCP). SCP is the lower lethal temperature for the freeze-avoidant, since the ice formation is intracellular (Sinclair et al. 2015). On top of the extreme low temperature many other factors may have significant effect on the insects' survival (Sinclair et al. 2003).

The North American oak lace bug (Corythucha arcuata (Say 1832) - Heteroptera: Tingidae) is a recent invader in Europe, first discovered in Italy in 2000 (Bernardinelli et al. 2000). In the last decade, it showed an explosive area expansion and has been reported from 20 European countries (Paulin et al. 2020). As almost all native deciduous oaks are suitable hosts for the oak lace bug (OLB), at least 30 million hectares of oak for- 
ests provide acceptable hosts for it in Europe (Csóka et al. 2019). Although there are major gaps in knowledge concerning the further spread and damage of the OLB, it seems potentially very dangerous both from an economic and an ecological point of view (Nikolic et al. 2019; Csóka et al. 2019; Paulin et al. 2020).

OLB adults stop feeding in late autumn (October/ November) and migrate to their overwintering microhabitats. These are under raised bark, bark crevices, branch forks covered by leaf litter, etc. Overwintering adults are rarely found on the soil surface under the leaf litter, but the vast majority of the overwintering bugs use tree trunks, branches and dead logs on the ground. No overwintering larvae have been found in Hungary so far. They finish overwintering and climb up on the trees starting from early/mid-April. It is assumed that the mild winters and early spring might help the further area expansion and outbreaks. However this is not yet supported by scientific results and no published information are known on temperature demands of OLB either.

In order to obtain information on its overwintering success, we conducted a simple field survey within three years at five Hungarian locations already invaded by the OLB. The finding of the first year's survey was already published (Csepelényi et al. 2017), but its results have also been incorporated in this study.

\section{Methods}

Adult oak lace bugs were collected from their overwintering microhabitats in the second half of March prior to their emergence (early/mid-April). In all three years, at all locations samples were taken from at least ten trees, normally providing different overwintering microhabitats (raised bark, bark crevices, branch forks covered by leaf litter, etc.). Sampling dates differed between years and locations mainly due to different spring weather conditions. The main aspect was to sample before the bugs leave the overwintering microhabitats, since the late sampling would have overestimated the mortality. Locations, dates of samplings and sample sizes are provided in Table 1. After keeping the bugs at room temperature $\left(20-22^{\circ} \mathrm{C}\right)$ for $24-36$ hours, living and dead bugs were counted. Temperature dates were obtained either from local meteorological stations or from the daily reports of the Hungarian Meteorological Service. Based on these data, the following temperature variables were calculated/considered:

- Average temperature of the period (average of the daily average temperatures).

- Average of the daily minimum temperature of the period.

- The lowest temperature measured in period.

- Lowest 10 -day running average of the daily minimum temperatures in the period.

The "period" always means the time window from December $1^{\text {st }}$ until the last day prior the sampling date. For example, December $1^{\text {st }} 2016$ - March $15^{\text {th }} 2017$ at Gyula. Measured and calculated temperature variables are provided in Table 2.

Mortality rates were correlated with the meteorological variables listed above.

\section{Results}

Mortality rates of the 9 year/location combinations (presented in Table 3) ranging from $9.1 \%$ to $58.5 \%$ show considerable variation. The average of all combinations merged is $30.6 \%$.

None of the four meteorological variables gave any significant correlation with the mortality rates at $95 \%$ significance level.

Table 1. Sample sizes (number of adult C. arcuata) and sampling dates (in bracket) in three years at five locations.

\begin{tabular}{|c|c|c|c|c|c|}
\hline Winter/Location & $\begin{array}{c}\text { Békéscsaba } \\
46.6728^{\circ} \mathrm{N} 21.1431^{\circ} \mathrm{E} \\
85 \mathrm{~m} \text { a.s.l. } \\
\end{array}$ & $\begin{array}{c}\text { Gyula } \\
46.6940^{\circ} \mathrm{N} 21.3350^{\circ} \mathrm{E} \\
86 \mathrm{~m} \text { a.s.l. } \\
\end{array}$ & $\begin{array}{c}\text { Mátrafüred } \\
47.8308^{\circ} \mathrm{N} 19.9658^{\circ} \mathrm{E} \\
355 \mathrm{~m} \text { a.s.l. } \\
\end{array}$ & $\begin{array}{c}\text { Szarvas } \\
46.8759^{\circ} \mathrm{N} 20.5314^{\circ} \mathrm{E} \\
87 \mathrm{~m} \text { a.s.l. } \\
\end{array}$ & $\begin{array}{c}\text { Szolnok } \\
47.2042^{\circ} \mathrm{N} 20.1814^{\circ} \mathrm{E} \\
86 \mathrm{~m} \text { a.s.l. } \\
\end{array}$ \\
\hline $2016 / 2017$ & $\begin{array}{c}3,187 \\
(03.20-24)\end{array}$ & $\begin{array}{c}201 \\
(03.16)\end{array}$ & 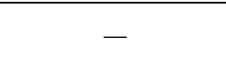 & $\begin{array}{c}683 \\
(03.30)\end{array}$ & \\
\hline 2018/2019 & - & $\begin{array}{c}1,329 \\
(03.20)\end{array}$ & $\begin{array}{c}386 \\
(03.29)\end{array}$ & - & $\begin{array}{c}4,929 \\
(03.21)\end{array}$ \\
\hline 2019/2020 & - & $\begin{array}{r}2,582 \\
(03.19) \\
\end{array}$ & $\begin{array}{l}1,816 \\
(03.19) \\
\end{array}$ & - & $\begin{array}{r}2,519 \\
(03.20) \\
\end{array}$ \\
\hline
\end{tabular}

Table 2. Temperature variables within three years at five locations.

\begin{tabular}{|c|c|c|c|c|c|c|}
\hline Temperature variables & Winter/Location & Békéscsaba & Gyula & Mátrafüred & Szarvas & Szolnok \\
\hline \multirow{3}{*}{ Average of daily average temperatures } & $2016 / 2017$ & 0.7 & 0.1 & - & 0.9 & - \\
\hline & $2018 / 2019$ & - & 2.4 & 2.0 & - & 2.8 \\
\hline & $2019 / 2020$ & - & 3.1 & 2.4 & - & 4.3 \\
\hline \multirow{3}{*}{ Average of the daily minimum temperatures } & $2016 / 2017$ & -2.8 & -3.3 & & -2.8 & \\
\hline & 2018/2019 & - & -1.2 & -1.3 & - & -0.9 \\
\hline & $2019 / 2020$ & - & -0.8 & -0.7 & - & 1.1 \\
\hline \multirow{3}{*}{ The lowest temperature measured } & $2016 / 2017$ & -19.0 & -18.0 & - & -19.0 & \\
\hline & $2018 / 2019$ & - & -7.7 & -9.3 & - & -13.0 \\
\hline & $2019 / 2020$ & - & -9.5 & -10.1 & - & -8.0 \\
\hline \multirow{3}{*}{ Lowest 10 days running average of the daily minimum temperatures } & $2016 / 2017$ & -8.1 & -7.5 & & -7.5 & \\
\hline & $2018 / 2019$ & - & -3.1 & -6.6 & - & -3.9 \\
\hline & $2019 / 2020$ & - & -3.1 & -2.5 & - & -1.2 \\
\hline
\end{tabular}


Table 3. Percentage of dead $C$. arcuata in samples collected in three years at five locations.

\begin{tabular}{lcccccc}
\hline Winter/Location & Békéscsaba & Gyula & Mátrafüred & Szarvas & Szolnok & Average \\
\hline $2016 / 2017$ & $21.4 \%$ & $51.7 \%$ & - & $44.1 \%$ & - & $39.1 \%$ \\
$2018 / 2019$ & - & $58.5 \%$ & $18.7 \%$ & - & $44.6 \%$ & $40.6 \%$ \\
$2019 / 2020$ & - & $13.0 \%$ & $9.1 \%$ & - & $14.4 \%$ & $12.2 \%$ \\
Average & - & $41.7 \%$ & $13.9 \%$ & - & $29.5 \%$ & $30.6 \%$ \\
\hline
\end{tabular}

\section{Discussion}

Bernardinelli (2006) compared the climatic conditions of the OLB's native range (Eastern USA and Canada) and Europe and concluded that most of Europe's climate may allow the further spread of the species. Zielinska \& Lis (2020) concluded that the climate in Southern Poland is suitable for the OLB, and the presence/abundance of oak forests may also increase the chance of its establishment. Our results seem to support their conclusions.

The mortality rates did not show significant correlation with our four meteorological variables. The 9 data points is likely not enough to reveal correlations if they are any. But it is already evident that the mortality rates are rather low, even during a relatively harsh winter (2016/2017).

It is clear that the overwintering mortality rates are influenced by many factors other than the extremely low winter air temperature. The state of the overwintering microhabitats (tree exposure, thickness of bark, etc.), number of thaw-freeze transitions, rate of temperature change, cumulative chill injury might be very different, resulting in different chances of survival (Sinclair et al. 2003).

The availability and quality of the pre-overwintering food quality also have important roles, both in the success of overwintering and the post-overwintering performance, as demonstrated by Zvereva (2002) for the leaf beetle, Chrysomela lapponica and by Trudeau et al. (2010) for Malacosoma disstria.

In warm periods during overwintering, insects may use their energy sources and this can have negative impacts on them on the longer term (Hahn \& Denlinger 2011; Sinclair 2015). It can be particularly important for insects starting overwintering with low energy reserve. In other words, insects starving before overwintering will have a lower chance to survive and even if they survive, they will have less resource to use for post-wintering activities (dispersal, mating, etc.). The relative importance of this aspect is likely becoming more important as warmer periods during winters are becoming more frequent.

In case of the OLB, the pre-overwintering starvation seems likely for location/year combinations we studied (except Mátrafüred 2018/2019). The abundance of the OLB was always high enough for overexploitation of food sources by late summer or early autumn, resulting in a uniform discoloration and desiccation of foliage on large contiguous territories. In this situation, the majority of the population either starved or had to feed on other secondary hosts (Rubus, Acer, etc.). But even so, the mortality rates remained relatively low. This may mean that winter low winter temperature itself is unlikely to restrict the further spread to the East, North and West.

Jun et al. (2010) studied the supercooling point (SCP) and the cold hardiness of the closely related Corythuca ciliata in China, where this species is an invasive pest of Platanus trees. The average SCP was $-11.49^{\circ} \mathrm{C}$ for males and $-9.54{ }^{\circ} \mathrm{C}$ for females. They found $C$. ciliata freeze-intolerant, but chill-tolerant, tolerating subzero temperatures by supercooling. It worth mentioning that supercooling points of a given species' individuals may show considerable variation geographically, monthly and inter annually as it was demonstrated by Vétek el al. (2020) for the invasive Aproceros leucopoda (Hymenoptera: Argidae). No similar information is known yet for the OLB, although our related cooperative experiments are already in progress.

\section{Conclusions}

Based on the results, the low winter temperatures themselves do not seem to restrict the further area expansion of the oak lace bug towards North, West or East. However, many factors other than winter temperature can influence the overwintering mortality of the oak lace bug. Additional studies (both in field and laboratory) are needed to clarify the potential climatic limitation of the further spread.

\section{Acknowledgment}

This study is supported by the Ministry of Agriculture and the OTKA 128008 research project sponsored by the National Research, Development and Innovation Office.

\section{References}

Bale, J. S., 1993: Classes of Insects Cold hardiness. Functional Ecology, 7:751-753.

Bernardinelli, I., 2000: Distribution of the oak lace bug Corythucha arcuata (Say) in northern Italy (Heteroptera Tingidae). Redia, LXXXIII:157-162. 
Bernardinelli, I., 2006: European host plants and potential distribution of Corythucha arcuata (Say) (Heteroptera: Tingidae). In: Csóka, Gy., Hirka, A., Koltay, A. (eds): Biotic damage in forests. Proceedings of the IUFRO Symposium (WP 7.03.10 "Methodolgy of forest pest and disease survey in Central Europe") held in Mátrafüred, Hungary, September 12-16, 2004. Budapest, Hungarian Forest Research Institute, p. 10-17.

Csepelényi, M., Hirka, A., Mikó, Á., Szalai, Á., Csóka, G., 2017: Overwintering success of the oak lace bug (Corythucha arcuata) in 2016/2017 at South-Eastern Hungary. Növényvédelem, 53:285-288.

Csóka, G., Hirka, A. Lakatos, F., 2010: Már a spájzban vannak... Növényvédelem, 46:547-550.

Csóka, G., Hirka, A., Szőcs, L., 2012: Rovarglobalizáció a magyar erdőkben. Erdészettudományi Közlemények, 2:187-198.

Csóka, G., Hirka, A., Mutun, S., Glavendekic, M., Mikó, Á., Szőcs, L. et al., 2019: Spread and potential host range of the invasive oak lace bug [Corythucha arcuata (Say. 1832) - Heteroptera: Tingidae] in Eurasia. Agricultural and Forest Entomology, 22:61-74.

Csóka, G., Pénzes, Z., Hirka, A., Mikó, I., Matosevic, D., Melika, G., 2009: Parasitoid assemblages of two invading black locust leaf miners. Phyllonorycter robiniella (Clemens. 1859) and Parectopa robiniella (Clemens. 1859) in Hungary. Periodicum Biologorum, 111:405-411.

Hahn, D. A., Denlinger, D. L., 2011: Energetics of insect diapause. Annual Review of Entomology, 56:103121.

Kos, K., Lacković, N., Melika, G. et al., 2020: Diversity and surge in abundance of native parasitoid communities prior to the onset of Torymus sinensis on the Asian chestnut gall wasp (Dryocosmus kuriphilus) in Slovenia, Croatia and Hungary. Journal of Forest Research, available on https://doi.org/10.1007/ s11676-020-01197-5

Jun, R-T., Wang, F., Xiao, Y-Y., 2010: Supercooling Capacity and Cold Hardiness of the Adults of the Sycamore Lace Bug, Corythucha ciliata (Hemiptera: Tingidae). Cryo Letters, 31:445-453

Leather, S., Walters, K., Bale, J., 1993: The Ecology of Insect Overwintering. Cambridge University Press, $255 \mathrm{p}$.

Marshall, E. K., Gotthard, K., Williams, C. M., 2020: Evolutionary impacts of winter climate change on insects. Current Opinion in Insect Science 2020, 41:54-62.

Neuvonen, S., Virtanen, T., 2015:Abiotic factors, climate variability of forest insect pests. In: Björkman, C., Niemalä, P.: Climate change and insect pests. $\mathrm{CABI}$ climate change series, 7:154-172.
Nikolić, N., Pilipović, A., Drekić, M., Kojić, D., Poljaković-Pajnik, L., Orlović, S. et al., 2019: Physiological responses of pedunculate oak (Quercus robur L.) to Corythucha arcuata (Say, 1832) attack. Archives of Biological Sciences, 71:167-176.

Panzavolta, T., Croci, F., Bracalini, M., Melika, G., Benedettelli, S., Tellini Florenzano, G. et al., 2018: Population Dynamics of Native Parasitoids Associated with the Asian Chestnut Gall Wasp (Dryocosmus kuriphilus) in Italy. Psyche: A Journal of Entomology, 2:1-13.

Paulin, M., Hirka, A., Eötvös, C. B., Gáspár, C., FürjesMikó, Á., Csóka, G., 2020. Known and predicted impacts of the invasive oak lace bug (Corythucha arcuata) in European oak ecosystems - a review. Folia Oecologica, 47:130-138.

Roques, A., 2010: Taxonomy. time and geographic patterns. In: Roques, A., Kenis, M., Lees, D., Lopez, C., Vaamonde, W., Rabitsch, Y-V., Roy. D. B. (eds): Alien terrestrial arthropods of Europe. BioRisk, 4:11-26.

Scaccini, D., Luka Vanishvili L., Tirello P., Walton, V.M., Carlo Duso, C., 2020: Lethal and sub-lethal effects of low-temperature exposures on Halyomorpha halys (Hemiptera: Pentatomidae) adults before and after overwintering. Scientific Reports, available on https://doi.org/10.1038/s41598-020-72120-5

Sinclair, B. J., 2015: Linking energetics and overwintering in temperate insects. Journal of Thermal Biology, 54:5-11.

Sinclair, B. J., Coello Alvarado, L. E., Ferguson, L. V., 2015: An invitation to measure insect cold tolerance: methods, approaches, and workflow. Journal of Thermal Biology, 53:180-197.

Sinclair, B. J., Vernon, P., Klok, J. C., Chown, S. L., 2003: Insects at low temperatures: an ecological perspective. Trends in Ecology and Evolution, 18:257-362.

Smith, R. M., Baker, R. H.A., Collins, D. W., Korycinska, A., Malumphy, C. P., Ostojá-Starzewski, J. C. et al., 2018: Recent trends in non-native, invertebrate, plant pest establishments in Great Britain, accounting for time lags in reporting. Agricultural and Forest Entomology, 20:496-504.

Trudeau, M., Mauffette, Y., Rochefort, S., Hans, E., Bauce, E., 2010: Impact of Host Tree on Forest Tent Caterpillar Performance and Offspring Overwintering Mortality. Environmental Entomology, 39:49504.

Tuba, K., Horváth, B., Lakatos, F., 2012: Inváziós rovarok fás növényeken. Nyugat-magyarországi Egyetem Kiadó, 120 p.

Turnock, W. J., Fields, P. G., 2005: Winter climates and coldhardiness in terrestrial insects. European Journal of Entomology, 102:561-576. 
Vétek, G., Fekete, V., Ladányi, M., Cargnus, E., Zandigiacomo, P., Oláh, R. et al., 2020: Cold tolerance strategy and cold hardiness of the invasive zigzag elm sawfly Aproceros leucopoda (Hymenoptera: Argidae). Agricultural and Forest Entomology, 22:231-237.
Zielińska, A., Lis, B., 2020: Ocena możliwości potencjalnej ekspansji prześwietlika dębowego Corythucha arcuata (Say, 1832), inwazyjnego gatunku z rodziny Tingidae (Hemiptera: Heteroptera), na tereny Polski. Heteroptera Poloniae-Acta Faunistica, 14:175-180. Zvereva, E. L., 2002: Effects of host plant quality on overwintering success of the leaf beetle Chrysomela lapponica (Coleoptera: Chrysomelidae). European Journal of Entomology, 99:189-195. 